\title{
SMC3 Gene
}

National Cancer Institute

\section{Source}

National Cancer Institute. SMC3 Gene. NCI Thesaurus. Code C24317.

This gene plays a role in chromosomal segregation during mitosis and is involved in cellular adhesion. 